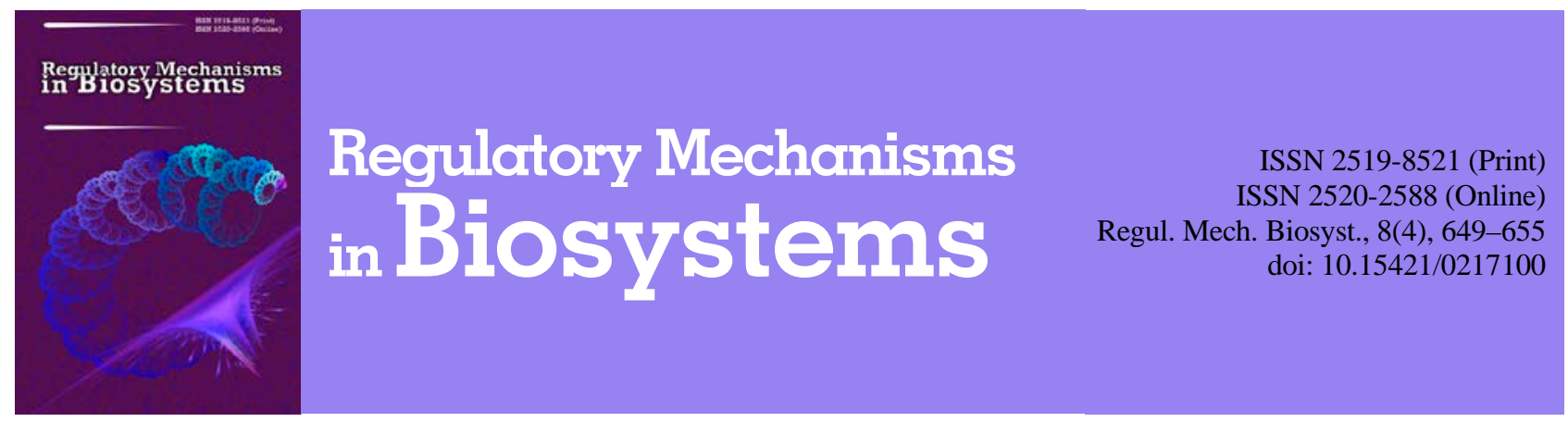

\title{
Morphometric parameters of the intestine and aggregated lymphatic nodules of meat rabbits
}

\author{
P. M. Gavrylin, M. O. Nikitina \\ Dnipro State Agrarian and Economic University, Dnipro, Ukraine
}

Article info

Received 07.10.2017

Received in revised form 29.10.2017

Accepted 01.11.2017

Dnipro State Agrarian and Economic University, Serhii Efremov Str., 25, Dnipro, 49600, Ukraine. Tel.: +38-097-969-46-96. E-mail:

morfologagro@gmail.com
Gavrylin, P. M., \& Nikitina, M. O. (2017). Morphometric parameters of the intestine and aggregated lymphatic nodules of meat rabbits. Regulatory Mechanisms in Biosystems, 8(4), 649-655. doi:10.15421/0217100

Nowadays, new breeds of rabbits are appearing with high productivity and rapid growth rate. These breeds require fresh research to be conducted in different fields, which include morphology of the intestine and gut-associated lymphoid tissue (GALT). The morphology of the intestine and GALT of meat rabbits are the investigated objects of the current research. We conducted the investigation on rabbits of different ages (1, 10, 20, 30, 60 and 90 days old). Each age group consisted of five animals. All veterinary ethical requirements were complied with. The body lengths and body masses were measured. Using t-coefficients, we estimated the range of variation of these parameters in each age group. The conclusion about this variation was taken. The masses and lengths of the different intestine parts were investigated as well. Using the obtained values, we provided a continuous numerical model to compute the mass and length of any intestine part of a rabbit of any age in the range from one to 90 days. This allowed us to represent the obtained empirical model by a plot for subsequent detailed study. We found that the changes in masses and lengths do not follow the same pattern for all intestine parts. For some intestine parts, this pattern is approximately linear in the range from one to 90 days; meanwhile for others, the changes in masses and lengths are quite complicated. We observed two local maximas of the growth rate for some intestine parts. Apart from the masses and lengths of the intestine parts, we accomplished macro analysis of the aggregated lymphoid nodules of each age group of animals. We estimated the index of gross area and the law by which it changes in each group. The research results presented here may be used as a basis for composing food ration, assessment of immune status and development of effective prevention and treatment against some diseases.

Keywords: small and large intestine; ilial diverticulum; vermiform appendix; gut-associated lymphoid tissue; average daily gain; growth of length

\section{Морфометричні показники кишечника та агрегованих лімфатичних вузликів кролів м'ясного напрямку використання}

\author{
П. М. Гаврилін, М. О. Нікітіна
}

Дніпровський державний аграрно-економічний університет, Дніпро, Україна

Поява нових порід кролів із підвищеною продуктивністю та прискореною інтенсивністю росту зумовлює необхідність досліджень у різних галузях, у тому числі морфології кишечника та його імунних структур. Результати цих досліджень необхідні як базові дані для складання раціону, визначення імунного статусу, розроблення ефективної профілактики та лікування деяких хвороб тварин. У дослідження залучені кролі різних вікових груп: 1, 10, 20, 30, 60 та 90-добового віку. Визначено інтервальні оцінки маси та довжини тіла, за якими встановлено, що їх приріст відбувається не рівномірно. За середніми значеннями вимірювань відділів кишечника кролів отримані моделі відносної зміни їх маси та довжини залежно від віку. Періоди найбільшого та найменшого приросту маси збігаються у 1) порожній $і$ прямій кишках, 2) сліпій, великій і малій ободових кишках. У порожній та прямій кишках період найменшого приросту маси реєстрували 3 першої доби народження до 10-ї доби розвитку, але найактивніше маса збільшується з 60-ї по 90-ту добу. Сліпій, великій та малій ободовим кишкам також властиві найповільніші зміни маси з 1-ї по 10-ту добу життя, але найбільший приріст відмічається від 20-ї по 30-ту добу постнатального онтогенезу. Виявлено збіг лінійного приросту у сліпій та великій ободовій кишках. На 20-ту добу постнатального онтогенезу в тонкому відділі кишечника макроскопічно виявлено агреговані лімфатичні вузлики, загальна площа яких до 90-ї доби життя нерівномірно збільшується.

Ключові слова: відділи кишечника; дивертикул клубової кишки; червоподібний відросток; агрегована лімфоїдна тканина; слизова оболонка кишечника; приріст маси; лінійний приріст 


\section{Вступ}

Кролівництво виступає як перспективна галузь тваринництва завдяки фізіологічним особливостям виду (плодючість і скороспілість) (Pechenkin et al., 2013) та корисним властивостям продукції, тому активно ведуться дослідження, спрямовані на визначення впливу на кролів умов утримання з урахуванням поведінки, рівня стресу та щільності утримання (Trocino et al., 2014), оцінювання відмінностей у туші, якості характеристик м'яса та м'язових волокон серед кролів різних порід і розмірів (Tumova et al., 2014).

Таким чином, постає питання збереження необхідних якостей продукції кролівництва та економічної ефективності виробництва, для успіху в чому необхідно знизити витрати на годування та смертність унаслідок захворювань шлунково-кишкового тракту (Tazzoli et al., 2014). Тому проводяться дослідження раціонів із визначенням впливу кількості білка на показники росту, вміст сечового азоту та загальний стан здоров'я кролів (Gidenne et al., 2013); обмеженого годування 3 високою енергетичною поживністю (Knudsen et al., 2014), крохмалю на ферментацію у сліпій кишці (Trocino et al., 2011) тощо. Завдяки подібним дослідженням у праці Fortun-Lamothe and Boullier (2007) установлено, що деякі поживні речовини, наприклад, жирні кислоти та клітковина, можуть бути використані для поліпшення імунної здатності тварин, оскільки вони беруть участь у розвитку імунної відповіді. Саме кишечник та його імунні структури відіграють важливу роль у забезпеченні імунного статусу тварин (Samoyliuk, 2011). Вагоме значення приділяється дослідженню морфології травної системи та iï лімфоїдних утворень, оскільки їх слизова оболонка постійно піддається антигенному впливу через корм (Korableva, 2011).

Кишковий канал - найбільша поверхня тіла, яка захищає внутрішне середовище від зовнішнього середовища (Sicherer et al., 2010; Camps-Bossacoma et al., 2017). Вага травного каналу у кроликів продуктивних порід складає приблизно 20\% від загальної маси тіла, при цьому шлунок і сліпа кишка виконують роль основних резервуарів (Margüenda et al., 2012). Основна функція кишечника полягає не тільки у процесах травлення та всмоктуванні поживних речовин (Sicherer et al., 2010; Camps-Bossacoma et al., 2017), а й у формуванні імунітету. У свою чергу, лімфоїдна тканина, що асоційована 3 його слизовою оболонкою, відіграє центральну роль у підтриманні гомеостазу (Vighi et al., 2008; Camps-Bossacoma et al., 2017). Вона містить майже 70\% імунних клітин усієї імунної системи, що захищає поверхню кишечника від потенційно шкідливих антигенів (Mowat et al., 2003; Camps-Bossacoma et al., 2017).

Тривалий контакт із поверхнею слизової оболонки травного тракту корму та продуктів його травлення спричиняє формування лімфоїдних вузликів (Korableva, 2011b). Агреговані лімфатичні вузлики - високоорганізовані лімфоїдні утворення кишечника, що розглядаються як вагомий компонент імунної системи організму. Вони беруть участь у процесі формування імунної відповіді, а також у лімфопоезі та рециркуляції лімфоцитів (Korableva, 2011a). Агреговані лімфатичні вузлики разом із червоподібним відростком являють собою невід'ємні та важливі компоненти імунної системи організму тварини. Найбільша кількість агрегованих лімфатичних вузликів міститься у тонкому відділі кишечника (Korableva, 2011a). За результатами досліджень Stoyanovskiy et al. (2014) установлено, що у слизовій оболонці дванадцятипалої кишки 6- та 12-місячних кролів агреговані лімфатичні вузлики не виявляються. У порожній кишщі їх близько 4-5. Агреговані лімфатичні вузлики округлої або дещо видовженої форми, виступають над поверхнею слизової оболонки. У клубовій кишщі наявний один агрегований лімфатичний вузлик округлої форми, а також специфічне для кролів утворення, яке міститься перед сліпою кишкою у вигляді дивертикулоподібного розширення з міцними стінками дивертикул клубової кишки. Сліпа кишка об'ємна, має перехвати, що розділяють кишку на окремі комірки, поступово звужується та закінчується сліпо переходячи в червоподібний відросток, для якого характерне потовщення стінок. Імунні структури в кінцевому відділі товстих кишок у кролів макроскопічно не виявлені (Stoyanovskiy et al., 2014).
Створюються нові породи 3 підвищеною продуктивністю та прискореною інтенсивністю росту для промислових цілей, які потребують додаткового вивчення морфологічних особливостей будови кишечника та асоційованих із його слизовою оболонкою імунних компонентів як необхідних базових даних, із подальшим застосуванням їх для складання раціону, визначення імунного статусу, розроблення ефективної профілактики та лікування деяких хвороб тварин.

Мета статті - виявити особливості вікової динаміки макрометричних показників кишечника та його імунних структур, асоційованих зі слизовою оболонкою, зокрема, агрегованих лімфатичних вузликів, у кролів м'ясного напряму використання, які відрізняються високими показниками швидкості росту тіла в період постнатального онтогенезу.

\section{Матеріал і методи досліджень}

Дослід проводили на базі Дніпровського державного аграрноекономічного університету. Всі маніпуляції з піддослідними тваринами проведені 3 дотриманням етичних норм i, відповідно до міжнародного та українського законодавства. Матеріал дослідження - кишечник (тонкий і товстий відділи) клінічно здорових груп кролів м'ясного напрямку використання 1, 10, 20, 30, 60 та 90-добового віку, по п'ять особин у кожній віковій групі. Прижиттєво зважували кожну тварину та вимірювали довжину тіла.

Після анатомічного препарування відбирали матеріал для визначення макрометричних і морфометричних показників кишечника, дослідження макроморфології, лінійних промірів і форми агрегованих лімфатичних вузликів. Зважували окремі відділи кишечника на аналітичних вагах Kern 440-35А з відтворюваністю 0,01 г. Лінійні проміри відділів кишечника (довжина, ширина) та агрегованих лімфатичних вузликів виконували за допомогою сантиметрової стрічки та лінійки з ціною поділки 1 мм.

У кожній віковій групі кролів вимірювали довжини та маси відділів кишечника. За отриманими вимірюваннями розраховували середні значення, що $є$ оцінками типової маси та довжини у кожній групі. За отриманими середніми значеннями параметрів розраховували відносні оцінки за формулою:

$$
z_{k}^{*}=\frac{\bar{x}_{k}}{\bar{X}_{90}} 100 \%,
$$

де $\bar{x}_{k}$ - середнє значення параметра (маси або довжини відділу кишечника), що вимірювався для $k$-ї вікової групи; $\bar{x}_{90}$ - середнє значення вимірювань параметра відділу кишечника кролів на 90ту добу розвитку; $z_{k}^{*}-$ оцінка параметра $k$-ї вікової групи кролів у процентах відносно значення оцінки параметра кролів на 90-ту добу; $k \in\{1,10,20,30,60,90\}$.

Оцінки дозволяють порівнювати динаміку росту відділів кишечника. За значеннями цих оцінок отримані неперервні числові моделі відносної зміни маси та довжини відділів кишечника залежно від віку кролів. Моделі обчислені за допомогою кусковонеперервної інтерполяції кубічними ермітовими поліномами (РСНІР). Характерна особливість обраного методу інтерполяції збереження характерної форми та монотонності функції, що інтерполюється (Fritsch et al., 1980).

\section{Результати}

Вимірювали масу та довжину тіла та кишечника шести вікових груп кролів по п’ять особин у кожній. Інтервальні оцінки маси та довжини тіла та маси та довжини кишечника неведені в таблиці 1 для кожної вікової групи кролів. Розкид оцінок параметрів у кожній віковій групі істотно менший за відстань між оцінками параметрів різних вікових груп. Це означає, що відмінність між групами зумовлена різними значеннями параметрів, а не похибками вимірювань. Аналіз значень оцінок (табл. 1) показує, що у постнатальному періоді онтогенезу приріст живої маси кролів відбува- 
ється не рівномірно. Від народження загальна маса тіла кроленяти дорівнює в середньому 53,2 г. Найменш інтенсивний набір маси тіла 3 1-ї по 20-ту добу розвитку, коли середньодобовий приріст маси становить близько 14,3 г за добу. 3 20-ї доби відмічали дещо прискорене збільшення живої маси 3 найактивнішим періодом 3 30-ї до 60-ї доби, з середньодобовим приростом близько 43,8 г на добу. У період з 60-ї по 90-ту добу набір маси тіла знижується до середнього значення 34,0 г за добу. Маса кролів м'ясного напрямку використання на 90-ту добу життя досягає близько 2960 г, тобто збілышується майже в 55 разів порівняно з початковою.

Таблиця 1

Оцінки маси та довжини тіла та кишечника кролів $(\mathrm{m} \pm \mathrm{SD}, \mathrm{n}=5)$

\begin{tabular}{ccccc}
\hline Доба життя & Маса тіла, г & Довжина тіла, см & Загальна маса кишечника, г & Загальна довжина кишечника, см \\
\hline 1 & $53,2 \pm 3,0$ & $10,5 \pm 1,1$ & $1,63 \pm 0,17$ & $72,9 \pm 1,0$ \\
10 & $201,8 \pm 4,3$ & $16,6 \pm 1,1$ & $5,20 \pm 0,26$ & $145,4 \pm 2,0$ \\
20 & $339,5 \pm 6,8$ & $23,2 \pm 1,3$ & $23,06 \pm 1,36$ & $31,3,7 \pm 4,7$ \\
30 & $625,5 \pm 8,6$ & $31,0 \pm 1,6$ & $39,24 \pm 2,18$ & $4,2 \pm 4,3$ \\
60 & $1940,0 \pm 114,0$ & $41,2 \pm 1,6$ & $58,91 \pm 0,91$ & $617,5 \pm 8,2$ \\
90 & $2960,0 \pm 96,2$ & $60,2 \pm 2,4$ & $106,74 \pm 1,88$ & 6,0 \\
\hline
\end{tabular}

Довжина тіла кролів у постембріональному періоді змінюється не лінійно та на перший день складає майже 10,5 см. До 30-і доби розвитку спостерігали відносно рівномірне збільшення довжини тіла, 3 найвищими показниками з 20-ї по 30-ту добу розвитку із середньодобовим приростом близько 0,78 см на добу. 3 30-ї доби відбувається різке зниження інтенсивності приросту довжини тіла, 3 найменшим показником у період від 30-ї до 60-ту добу розвитку і становить у середньому 0,34 см за добу. До 90-ї доби збільшується лінійний приріст довжини тіла та збільшується майже в 10 разів від показника довжини, встановленого на першу добу життя.

Загальна маса кишечника на перший день постембріонального розвитку становить близько 1,63 г. Приріст загальної маси кишечника (тонкого та товстого відділів) найменш інтенсивний у період з 1-ї по 10-ту добу із середньодобовим збільшенням маси органа близько 0,36 г за добу. Найактивніше кишечник набирає масу у період з 20-ї по 30-ту добу, коли приріст становить у середньому 1,70 г на добу. Від 30-ї доби інтенсивність набору маси кишечника знижується, а з 60-ї по 90-ту добу розвитку - збільшується до майже 1,59 г за добу. На 90-ту добу розвитку абсолютна маса кишечника в середньому складає 106,74 г, що в 65 разів більше за визначену масу в першу добу після народження.

На першу добу постнатального онтогенезу загальна довжина кишечника кроленят становить близько 72,9 см. Від народження спостерігається відносно активний період збільшення лінійного приросту, але найінтенсивніший розвиток припадає на 10-20-ту добу із середньодобовим збільшенням близько 10,3 см за добу. Після 20-ї доби відзначили зниження інтенсивності змін загальної довжини кишечника, 3 найменшим показником на 30-60-ту добу зі значенням приросту в середньому на 3,6 см на добу. До 90-ї доби лінійний приріст дещо збільшується та кінщеве значення загальної довжини кишечника в середньому дорівнює 617,8 см, що у 8,5 раза більше за початкову довжину.

Оцінки дозволяють порівнювати динаміку росту відділів кишечника між собою. На рисунку 1 за отриманими числовими моделями зображені графіки відносної зміни маси відділів кишечника. Вертикальними лініями показано довірчий інтервал для нормованих оцінок математичного сподівання маси відділів кишечника $(\mathrm{P}=0,10)$.

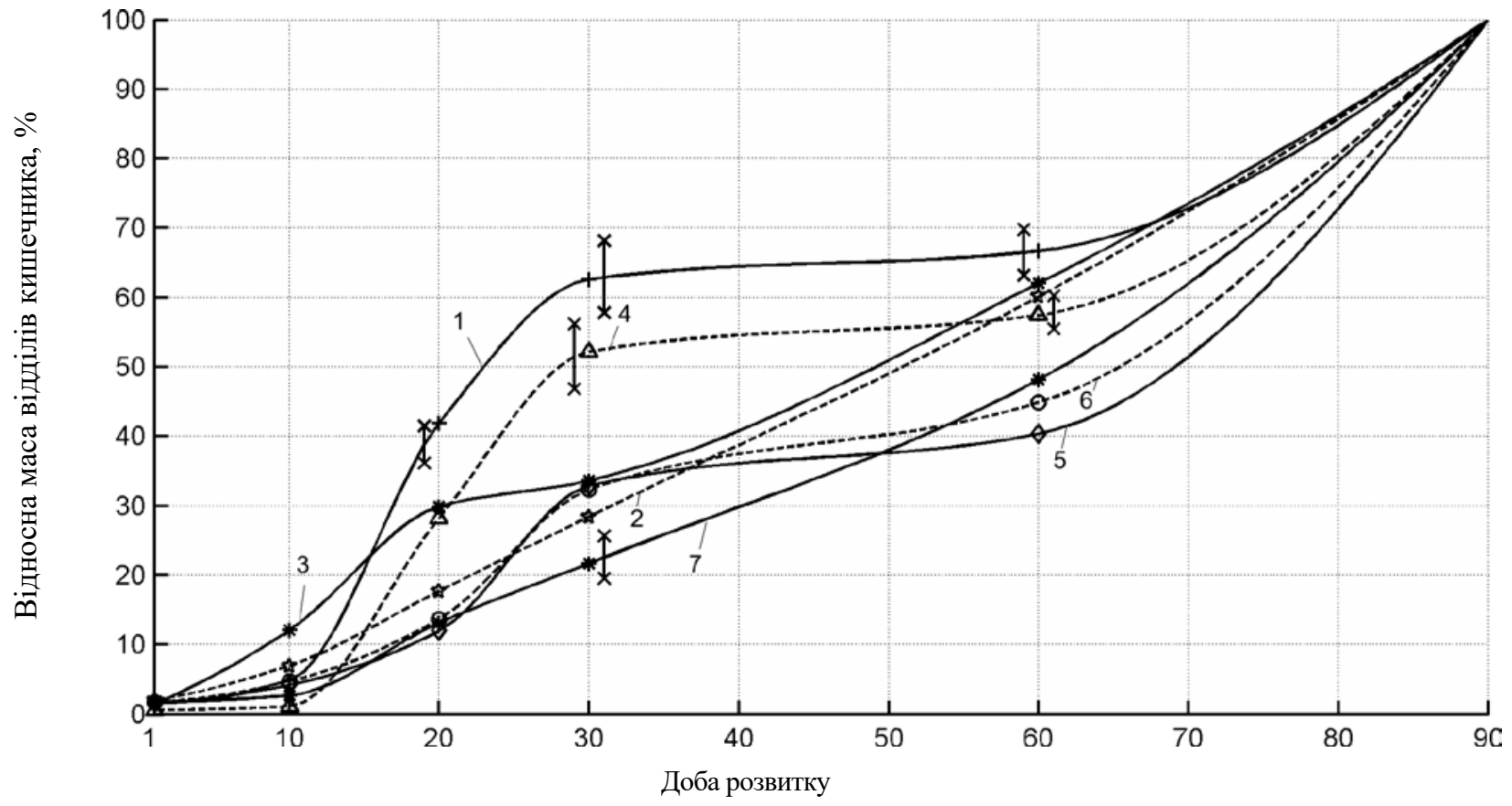

Рис. 1. Відносна зміна очікуваної маси (у відсотках) відділів кишечника залежно від доби життя: 1 - дванадцятипала кишка, 2 - порожня кишка, 3 - клубова кишка, 4 - сліпа кишка, 5 - велика ободова кишка, 6 - мала ободова кишка, 7 - пряма кишка

Використовуючи дані таблиці 2 та рисунка 1, можна розрахувати абсолютну масу кожного відділу кишечника з першого по 90-ту добу постнатального розвитку. На рисунку 1 спостерігали певні особливості у відповідні постембріональні періоди приросту маси кожного відділу кишечника. Для більшості відділів найменш активний етап приросту маси до 10-ї доби та найінтенсивніший - 3 10-ї по 20-ту добу постнатального онто- генезу. Найменше змінюється абсолютна маса порожньої кишки (збільшується в 49 разів) та найбільше - сліпої (зростає в 170 разів). Збігаються періоди найбільшої та найменшої активності приросту маси у таких відділах: 1) порожній та прямій; 2) сліпій, великій і малій ободових кишках. Для першої групи характерно, що період меншого приросту маси припадає на 110-ту добу розвитку та найінтенсивніше маса збільшується 3 
60-ї по 90-ту добу. Другій групі також властиві найповільніші зміни у масі на 1-10-ту добу життя, але найактивніший приріст припадає на 20-30-ту добу постнатального розвитку.

\section{Таблиця 2}

Оцінки маси та довжини кожного відділу кишечника на 90-ту добу розвитку $(\mathrm{x} \pm \mathrm{SD}, \mathrm{n}=5)$

\begin{tabular}{lcc}
\hline \multicolumn{1}{c}{ Відділ кишечника } & Маса відділу, г & Довжина відділу, см \\
\hline Дванадцятипала кишка & $9,79 \pm 0,14$ & $66,2 \pm 1,9$ \\
Порожня кишка & $28,77 \pm 0,54$ & $306,0 \pm 1,0$ \\
Клубова кишка & $9,70 \pm 0,30$ & $40,2 \pm 1,9$ \\
Сліпа кишка & $22,22 \pm 0,45$ & $55,6 \pm 0,9$ \\
Велика ободова кишка & $11,44 \pm 0,73$ & $25,3 \pm 0,7$ \\
Мала ободова кишка & $8,69 \pm 0,43$ & $20,7 \pm 1,0$ \\
Пряма кишка & $16,13 \pm 0,29$ & $103,8 \pm 0,8$ \\
\hline
\end{tabular}

Серед відділів кишечника найменші показники початкової абсолютної маси спостерігаються у дванадцятипалій $(0,16 \pm 0,03$ г), клубовій $(0,14 \pm 0,03$ г), сліпій $(0,13 \pm 0,04$ г), великій $(0,18 \pm 0,02$ г) та малій ободових $(0,15 \pm 0,02$ г) кишках, але найнижче значення співвідношення до кінцевої маси відділу має сліпа кишка (близько $0,58 \%$ ). Найважчий відділ на першу добу життя - порожня кишка, абсолютна вага якої становить $0,59 \pm 0,03$ г, за співвідношення до маси на 90-ту добу розвитку значення близько 2,1\%. Для дванадцятипалої кишки характерний повільний приріст маси від народження до 10-ї доби розвитку, після чого спостерігається найінтенсивніше збільшення ваги відділу протягом наступних 10 діб, яке дорівнює близько 0,36 г на добу. Після 20-ї доби спостерігається поступове зменшення набору маси, з мінімальним значенням у період 30-60-ї доби, що становить у середньому 0,013 г за добу. Маса дванадцятипалої кишки на 90-ту добу розвитку в середньому складає 9,79 г, що у 52 рази перевищує вихідну масу.

Порожній кишці, з початковою в постнатальний період масою $0,59 \pm 0,03$ г, притаманний найповільніший період приросту від народження до 10-ї доби життя, який дорівнює близько 0,14 г на добу. У подальшому спостерігали відносно рівномірне збільшення маси відділу у період із 10-ї по 60-ту добу, після якого за наступні 30 діб відбувається активний приріст маси в середньому на 0,38 г на добу. Кінцева, на момент завершення досліду (90-та доба), маса складає близько 28,8 г, яка більша за початкову в 49 разів.

Приріст постембріональної маси клубової кишки має відносно повільний період до 10-ї доби, після якої починається найактивніший набір маси до 20-ї доби, якому відповідає збільшення в середньому на 0,17 г за добу. 3 20-ї по 30-ту добу відбувається найінтенсивніший приріст маси, що становить близько 0,31 г на добу. До 90-ї доби спостерігали прискорення набору маси 3 подальшим відносно рівномірним іії збільшенням із кінцевою вагою відділу майже 9,7 г, тобто в 72 рази більше маси, встановленої на першу добу життя кроленяти.

Дивертикул клубової кишки як специфічне утворення відповідного відділу має власні закономірності приросту маси. На першу добу життя його маса дорівнює $0,01 \pm 0,002$ г. Найповільніший набір маси з 10-ї по 20-ту добу розвитку, і відповідає в середньому 0,005 г за добу, після чого спостерігали незначне збільшення маси. Після 30-ї доби характерний інтенсивніший приріст маси 3 максимальним значенням на 60-90-ту добу, що становить близько 0,09 г на добу. Кінцева абсолютна маса дивертикулу клубової кишки складає 5,45 \pm 0,07 г, отже, зростає у 400 разів порівняно з початковою масою.

У сліпій кишці з першого дня до 10-ї доби відмічали найменш активний період приросту маси зі значенням близько 0,01 г на добу. 3 10-ї по 20-ту добу відбувається найактивніше збільшення маси в середньому по 0,60 г на добу, а до 30-ї доби приріст маси незначно зменшується. До 90-ї доби збільшення маси сповільнюється та кінцеве значення в середньому дорівнює 22,2 г, що у 173 рази перевищує вихідну масу цього відділу.

Червоподібний відросток має подібні до сліпої кишки закономірності набору маси. На першу добу постнатального роз- витку його маса склала $0,04 \pm 0,01$ г. До $10-і ̈$ доби реєстрували найменш інтенсивний період набору маси, що становив у середньому 0,007 г на добу, а з 10-ї по 20-ту добу - найактивніший, близько 0,12 г за добу. У подальшому швидкість набору маси знижується, на 90-ту добу становить близько 6,0 г, тобто перевищує масу, встановлену на першу добу життя, у 137 разів.

Для великої ободової кишки встановили найповільніші постембріональні періоди збільшення маси на 1-10-ту та 30 60-ту добу постембріонального розвитку із середньодобовим приростом близько 0,03 г на добу. Найінтенсивніший набір маси припадав на 20-30-ту добу, що становив у середньому 0,24 г за добу та 60-90-ту добу - близько 0,23 г на добу. Маса великої ободової кишки на 90-ту добу становила 11,44 г, отже, початкова маса збільшується в 65 разів.

Збільшення показнику маси малої ободової кишки найменш інтенсивне від дня народження до 10-ї доби, і складає близько 0,03 г за добу. Найактивніший приріст маси припадає на період 20-30-ї доби та дорівнює в середньому 0,16 г на добу, після чого дещо знижується. На 60-90-ту добу маса знов активно зростає близько 0,16 г за добу до кінцевого середнього значення 8,69 г, що у 56 разів більше, ніж встановлена маса на першу добу життя.

Пряма кишка на першу добу постнатального онтогенезу має абсолютну масу $0,29 \pm 0,03$ г. На $1-10$-ту добу розвитку спостерігали найповільніший проміжок приросту маси в середньому на 0,01 г за добу, після чого прискорюється інтенсивність набору маси 3 найактивнішим показником на 60-90ту добу близько 0,28 г на добу. На 90-ту добу маса відділу дорівнює 16,1 г, тобто у 55 разів перевищує початкове значення.

Для вказаних вікових групп, окрім маси відділів, кишечника досліджували зміну їх довжини. Отримані числові моделі зображені у вигляді графіків (рис. 2).

За даними таблиці 2 та рисунка 2, можна розрахувати довжину відділу кишечника з 1-ї по 90-ту добу постембріонального розвитку для кожного відділу кишечника. Найменше змінюється абсолютна довжина клубової кишки (збільшується у 4,5 раза) та найбільше - сліпої (зростає у 16 разів). Збігаються періоди найбільшої та найменшої активності лінійного приросту у сліпій $\mathrm{i}$ великій ободовій кишках, тобто найактивніший лінійний приріст спостерігається з 20-ї по 30-ту добу життя, після якого спостерігається різке уповільнення з найменшим показником на 30 60-ту добу. Найкоротший відділ на першу добу життя мала ободова кишка, яка має абсолютну довжину $2,76 \pm 0,17$ см і найдовший відділ - порожня кишка довжина якої складає $37,18 \pm 0,16 \mathrm{~cm}$.

Абсолютна довжина дванадцятипалої кишки на першу добу постнатального розвитку $-6,36 \pm 0,11$ см. Лінійний приріст у дванадцятипалій кишці найбільше виражений із 10-ї по 20-ту добу та становить у середньому 1,83 см за добу. Спостерігається незначне зменшення швидкості лінійного приросту до 30-ї доби. Найменша інтенсивність збільшення довжини відділу - 3 30-ї по 60-ту добу, дорівнює близько 0,14 см на добу. До 90-ї доби незначне прискорення росту довжини відділу 3 кінцевим показником близько 66,2 см, тобто на порядок перевищує початкове значення довжини відділу.

Найактивніше у порожній кишці збільшення довжини відбувається з 10-ї по 20-ту добу після народження (середньодобовий приріст - близько 4,0 см за добу). Із 20-ї по 30-ту добу - різке зниження лінійного приросту з мінімальним значенням близько 0,88 см на добу. Довжина відділу збільшуеться до 90-ї доби розвитку, на який становить майже 306 см, що увосьмеро більше за значення встановленого на першу добу.

Довжина клубової кишки на першу добу постембріонального періоду складає $8,84 \pm 0,23$ см. Найбільший лінійний приріст відмічається з 1-ї по 10-ту добу розвитку, що має середньодобове значення близько 0,83 см за добу. Після чого поступово сповільнюється до 20-ї доби, падає 3 найменшою інтенсивністю у збільшенні довжини відділу у період з 30-і по 60-ту добу та становить 0,08 см на добу. До 90-ї доби розвитку довжина відділу збільшується уп'ятеро $з$ початкової та в середньому дорівнює 40,2 см. 


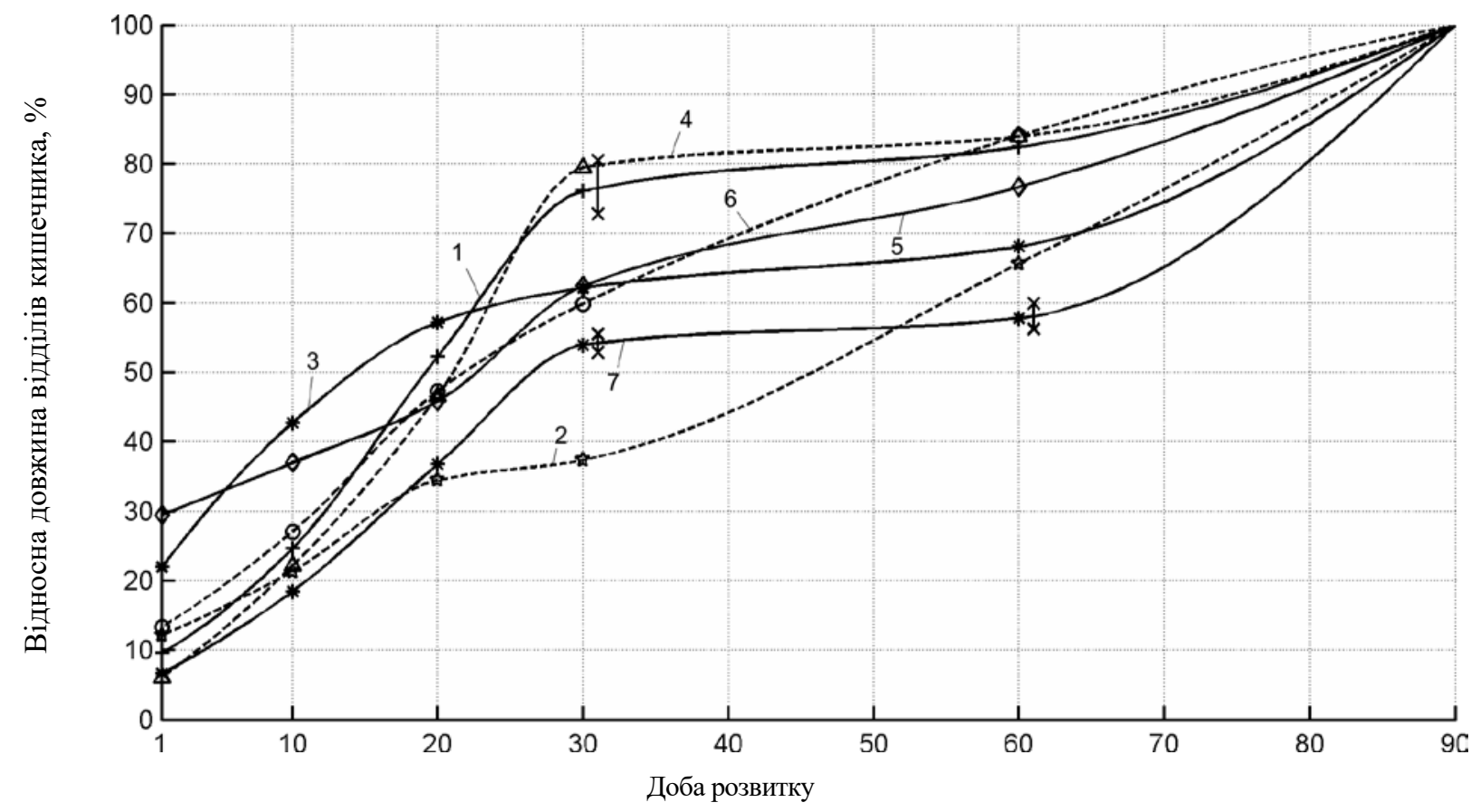

Рис. 2. Відносна зміна (\%) очікуваної довжини відділів кишечника залежно від доби життя: 1 - дванадцятипала кишка, 2 - порожня кишка, 3 - клубова кишка, 4 - сліпа кишка, 5 - велика ободова кишка, 6 - мала ободова кишка, 7 - пряма кишка

Дивертикул клубової кишки на першу добу постнатального онтогенезу має початкову довжину $0,40 \pm 0,07$ см. На відміну від клубової кишки, їі дивертикул з 1-ї по 10-ту добу розвитку має найактивніший період лінійного приросту і складає в середньому 0,02 см за добу. 3 10-ї доби відбувається прискорення збільшення довжини та найінтенсивніше - 3 20-ї по 30-ту добу з середньодобовим значенням близько 0,08 см на добу. Після 30-ї доби сповільнюється лінійний приріст, кінцева довжина на 90-ту добу становить $4,06 \pm 0,19$ см, що перевищує початкову довжину удесятеро.

Абсолютна довжина сліпої кишки на першу добу постембріонального розвитку дорівнює $3,38 \pm 0,15$ см. Від народження спостерігається відносно рівномірне збільшення довжини відділу до 20-ї доби. Найбільше зростає показник лінійного приросту з 20-і по 30-ту добу та складає в середньому 1,83 см за добу та різко знижується - 3 30-ї по 60-ту добу із середньодобовим значенням близько 0,08 см на добу. До 90-ї доби відбувається незначне прискорення збільшення довжини. Кінщева абсолютна довжина відділу збільшилась у 16 разів (близько 55,6 см).

Червоподібний відросток у першу добу постнатального періоду займає майже половину довжини сліпої кишки, що відповідає $1,6 \pm 0,1$ см. Максимальний та мінімальний періоди лінійного приросту червоподібного відростка не збігаються із розвитком сліпої кишки та відповідають періодам з 1-ї по 10-ту добу - із середньодобовим збільшенням близько 0,36 см за добу, і з 10-ї по 20-ту в середньому на 0,02 см за добу, відповідно. До 90-ї доби абсолютна довжина відділу збілышується в 9,5 раза від початкової та становить майже половину від довжини сліпої кишки близько 15,2 cм.

Велика ободова кишка від народження має абсолютну довжину 7,46 $\pm 0,09$ см. Від першої доби збільшується приріст довжини відділу та найінтенсивніший період відзначається з 20-ї по 30-ту добу розвитку в середньому на 0,42 см за добу. Найменш активний лінійний приріст припадає на період з 30-ї по 60-ту добу розвитку та становить близько 0,12 см на добу з подальшим незначним прискоренням. На 90-ту добу абсолютна довжина відділу зростає утричі від початкової та у середньому дорівнює 25,3 см.

Для малої ободової кишки характерний відносно інтенсивний лінійний приріст від народження з найбільшим показником у період 3 10-ї по 20-ту добу постембріонального розвитку в середньому по 0,42 см на добу. Після 20-ї доби відмічається поступове зниження інтенсивні зміни абсолютної довжини відділу з найменшим значенням з 60-ї по 90-ту добу близько 0,11 см за добу. Кінцеве значення абсолютної довжини малої ободової кишки близько 20,7 см, що перевищує довжину, встановлену на першу добу життя в 7,5 раза.

Абсолютна довжина прямої кишки на першу добу постнатального періоду дорівнює $6,92 \pm 0,16$ см. Найактивніший лінійний приріст відділу відбувається з 10-ї по 20-ту добу розвитку в середньому на 1,9 см щоденно, а найменш інтенсивний - 3 30-ї по 60-ту добу в середньому по 0,13 см за добу. До 90-ї доби розвитку довжина прямої кишки становить майже 103,8 см, що в 15 разів більше, ніж початкова.

Окрім маси та довжини кишечника досліджували агреговані лімфатичні вузлики, асоційовані зі слизовими оболонками кишечника. Вони макроскопічно виявляються з 20-ї доби постнатального онтогенезу на антибрижовій поверхні тонкого відділу кишечника та мають округло-овальну форму. Збільшення їх площі відбувається не рівномірно з найменшою інтенсивністю на 20-30-ту добу.

На кінці дванадцятипалої кишки у кролів 20-добового віку виявили один агрегований лімфатичний вузлик, довжина та ширина якого дорівнюють $0,66 \pm 0,05$ і 0,54 $\pm 0,05$ см, відповідно. У порожній кишщі вони містились у кількості 5 штук на різній відстані один від одного $з$ лінійними промірами близько $0,61 \times 0,52 \mathrm{~cm}$. На деякій відстані від початку клубової кишки виявляли один агрегований лімфатичний вузлик довжиною $0,56 \pm 0,09$ і шириною $0,44 \pm 0,05$ см. Загальна площа агрегованих лімфатичних вузликів у кролів 20-добового віку становила близько $1,79 \mathrm{~cm}^{2}$.

На 30-ту добу постнатального розвитку в дванадцятипалій кишці також наявний один агрегований лімфатичний вузлик із лінійними промірами $0,70 \pm 0,10 \times 0,60 \pm 0,07 \mathrm{~cm}$. У порожній кишці вони нерівномірно розміщені по їі довжині загальною кількістю 5 штук, довжина яких становила близько $0,66 \mathrm{~cm}$, а ширина близько 0,55 см. На початку клубової кишки наявний один агрегований лімфатичний вузлик із довжиною $0,62 \pm 0,07$ см і шириною $0,54 \pm 0,05$ см. Ці структури на 30 -ту добу розвитку мали загальну площу майже $2,05 \mathrm{~cm}^{2}$.

3 30-ї по 60-ту добу відмічається найактивніше збільшення показників площі агрегованих лімфатичних вузликів. На 60-ту добу агрегований лімфатичний вузлик дванадцятипалої кишки має показники: довжина $-1,20 \pm 0,17$ см, ширина $-0,94 \pm 0,11$ см. Відповідні структури порожньої кишки асиметрично розміщені, кількістю 5 штук, мали лінійні проміри близько 1,22 × 0,94 см. У верхній третині клубової кишки виявляли один агрегований лімфатич- 
ний вузлик із довжиною $1,32 \pm 0,19$ см і шириною 1,02 $\pm 0,13$ см. Загальна площа агрегованих лімфатичних вузликів до 60-ї доби досягає близько $6,5 \mathrm{~cm}^{2}$.

Дванадцятипала кишка кролів на 90-ту добу життя має один агрегований лімфатичний вузлик, довжина якого складає $1,88 \pm$ 0,16 см, а ширина $-1,30 \pm 0,18$ см. У порожній кишці ці структури мають лінійні проміри близько 1,76 × 1,18 см. Агрегований лімфатичний вузлик клубової кишки довжиною $1,72 \pm 0,08$ см і шириною 1,26 \pm 0,11 cм. До 90-добового віку загальна площа агрегованих лімфатичних вузликів досягає майже $11,84 \mathrm{~cm}^{2}$, тобто збільшується в 6,6 раза порівняно 3 показником, отриманим на 20-ту добу розвитку.

\section{Обговорення}

Згідно $з$ даними морфометрії кишечника та його агрегованих лімфатичних вузликів кролів різних порід та вікових груп інших авторів установлено певні відмінності. За результатами досліджень Nikitchenko et al. (2013), жива маса диких кролів дорівнювала у самців близько 2,1 кг, а самок - 2,3 кт. Під час дослідження м'ясних порід (фландр, білий великан, французький баран) Реchenkin et al. (2013) встановили, що їх ріст відбувається достатньо швидко: у віці 90 діб їх маса перевищуе 2 кг, а до 6-місячного віку 4,3-5,5 кт. При цьому найбільші середньодобові прирости спостерігали на третій місяць розвитку, після чого вони знижувалися. У дослідженні Vakulenko et al. (2016a, 2016b) вищу активність росту спостерігали до двомісячного віку, після чого вона знижується.

За даними Shubina and Choporova (2015), загальна довжина кишечника домашнього кролика складає близько 4-6 м, у дикого кролика вона становить близько $465 \mathrm{~cm}$ (Nikitchenko et al., 2015). У результатах досліджень Stoyanovskiy et al. (2014) довжина кишечника самців кролів у 6 та 12 місяців становить близько 588 та 568 см, відповідно.

В аналізі даних Balakirev et al. (2012) м'ясо-шкурні породи мають кращий розвиток товстого відділу кишечника, ніж м'ясні. А у м'ясних порід краще розвинений тонкий відділ кишечника.

Агреговані лімфатичні вузлики в найбільшій кількості розміщуються у тонкому відділі кишечника ссавців, при цьому їх кількість у слизовій оболонці тонкої кишки кролів від 3 до 15 (Korableva, 2011a). Однак Stoyanovskiy et al. (2014) зазначили, що агреговані лімфатичні вузлики у дванадцятипалій кишці відсутні. У слизовій оболонці порожньої кишки макроскопічно виявляли перший агрегований лімфатичний вузлик на початку кишки. Їх кількість у 6-місячних кролів становила 4,2 $\pm 0,14$ шт., із середньою довжиною $-1,45 \pm 0,09$ см. У кролів на 12-й місяць життя агрегованих лімфатичних вузликів було 4,8 $\pm 0,1$ шт., але з меншою середньою довжиною - 1,18 $\pm 0,10$ см. За дослідженнями клубової кишки кролів на 6-й та 12-й місяць реєстрували один агрегований лімфатичний вузлик довжиною відповідно 1,8 $\pm 0,12$ та 1,1 $\pm 0,05$ см.

Ці дані підтверджують наявність певних відмінностей у динаміці розвитку тіла, кишечника та його агрегованих лімфатичних вузликів у кролів залежно від породи та віку.

\section{Висновки}

Приріст маси тіла кролів у постнатальному розвитку відбувається нерівномірно і зростає до 90-ї доби у 55 разів, за той же період довжина тіла збілышується лише у 8,5 раза 3 початкової. Їх найбільш і найменш активні інтервали не збігаються. Найменш інтенсивний приріст маси тіла спостерігається з 1-ї по 20-ту добу життя, а найінтенсивніший - 3 30-ї по 60-ту добу постнатального онтогенезу. Найбільше зростання довжини тіла припадає на період 20-30-ї доби життя, після чого відбувається найповільніший лінійний приріст до 60-ї доби розвитку.

Закономірність приросту маси та довжини кишечника по відділах різна. Для більшості відділів кишечника найменше зростання маси відбувається до 10-і доби, найбільше - 3 10-ї по 20-ту добу постембріонального розвитку. До 90-ї доби найменше змінюється абсолютна маса порожньої кишки, найбільше - сліпої. Найінтен- сивніший період лінійного приросту відділів кишечника - 3 10-ї по 20-ту добу, як і приріст маси, а найменші зміни довжини спостерігаються з 30-ї по 60-ту добу. Найменше змінюється абсолютна довжина клубової кишки, а найбільше - сліпої. Відмічається подібність у періоди найбільшого та найменшого приросту маси у таких відділах: 1) порожній і прямій; 2) сліпій, великій і малій ободових кишках. У першій групі період меншого приросту маси становить із дня народження до 10-ї доби розвитку, найактивніше маса збільшується з 60-ї по 90-ту добу. Другій групі також властиві найповільніші зміни у масі з 1-ї по 10-ту добу життя, але найінтенсивніший приріст припадає на 20-30-ту добу постнатального розвитку. Збігаються періоди найбільшої та найменшої активності лінійного приросту відділів кишечника лише у сліпій $і$ великій ободовій кишках: найактивніший лінійний приріст спостерігається з 20-ї по 30-ту добу життя, після якого настає різке сповільнення з найменшим показником у 30-60-ту добу.

Агреговані лімфатичні вузлики макроскопічно виявляються на 20-ту добу постнатального розвитку з антибрижового боку кишечника овально-округлої форми. Їх загальна площа з 20-ї по 90-ту добу життя не рівномірно збільшується майже усемеро.

\section{References}

Balakirev, N. A., Nihmatullin, R. M., \& Tinaeva, E. A. (2012). Interemye osobennosti krolikov osnovnykh porod, razvodimykh v Rossiyskoy Federatsii [Interior features of rabbits of the main breeds bred in the Russian Federation]. Vestnik Orlovskoho Hosudarstvennoho Ahramoho Universiteta, 4(12), 76-79 (in Russian).

Bianospino, E., Moura, A. S. A. M. T., Wechsler, F. S., Fernandes, S., \& Dal-PaiSilva, M. (2008). Age-ralated changes in muscle fiber type frequencies and cross-sectional areas in straightbred and crossbred rabbits. Animal, 2(11), $1627-1632$.

Buijs, S., Keeling, L. J., Rettenbacher, S., Maertens, L., \& Tuyttens, F. A. M. (2011a). Glucocorticoid metabolites in rabbit faeces influence of environmental enrichment and cage size. Physiology and Behavior, 104, 469-473.

Buijs, S., Keeling, L. J., \& Tuyttens, F. A. M. (2011b). Behaviour and use of space in fattening rabbits as influenced by cage size and enrichment. Applied Animal Behaviour Science, 134, 229-238.

Buijs, S., Keeling, L. J., Vangestel, C., Baert, J., Vangeyte, J., \& Tuyttens, F. A. M. (2011c). Assessing attraction or avoidance between rabbits: Comparison of distance-based methods to analyse spatial distribution. Animal Behaviour, 82, 1235-1243.

Camps-Bossacoma, M., Perez-Cano, F. J., Franch, A., Untersmayr, E., \& Castell, M. (2017). Effect of a cocoa diet on the small intestine and gut-associated lymphoid tissue composition in an oral sensitization model in rats. Journal of Nutritional Biochemistry, 42, 182-193.

Fortun-Lamothe, L., \& Boullier, S. (2007). A review on the interactions between gut microflora and digestive mucosal immunity. Possible ways to improve the health of rabbits. Livestock Science, 107(1), 1-18.

Fritsch, F. N., \& Carlson, R. E. (1980). Monotone piecewise cubic interpolation. SIAM Journal on Numerical Analysis, 17(2), 238-246.

Gidenne, T., Combes, S., \& Fortun-Lamothe, L. (2012). Feed intake limitation strategies for the growing rabbit: Effect on feeding behaviour, welfare, performance, digestive physiology and health: A review. Animal, 6, 1407-1419.

Gidenne, T., Kerdiles, V., Jehl, N., Arveux, P., Eckenfelder, B., Briens, C., Stephan, S., Fortune, H., Montessuy, S., \& Muraz, G. (2013). Protein replacement by digestible fibre in the diet of growing rabbits: 2-Impact on performances, digestive health and nitrogen output. Animal Feed Science and Technology, 183(3), 142-150.

Korableva, T. P. (2011a). Limfoidnye obrazovania kishechnika mlekopitaiushchikh [Lymphoid formations of intestine of mammals]. Naukovi Pratsi Pivdennoho Filialu Natsionalnyi Universytet Bioresursiv i Pryrodokorystuvannia Ukrainy Krymskyi Ahrotekhnolohichnyi Universitet Seria Veterinarni nauki, 133, 86-92 (in Russian).

Korableva, T. P. (2011b). Topohraficheeskie osobennosti odinochnykh limfoidnykh uzelkov kishechnika teliat [Topographical features of single lymphoid nodules of intestine of calves]. Immunologiya Seria Veterinarna Meditsina, 2, 26-28 (in Russian).

Knudsen, C., Combes, S., Briens, C., Coutelet, G., Duperray, J., Rebours, G., \& Gidenne, T. (2014). Increasing the digestible energy intake under a restriction strategy improves the feed conversion ratio of the growing rabbit without negatively impacting the health status. Livestock Science, 169, 96-105.

Mowat, A. M. (2003). Anatomical basis of tolerance and immunity to intestinal antigens. Nature Reviews Immunology, 3, 331-41. 
Nikitchenko, V. E., Naumova, E. I., \& Shuber, S. S. (2015). Morfplohicheskoe stroenie zheludochno-kishechnoho tracta krolikov [Morphological structure of the gastrointestinal tract of the rabbit]. Vestnik Rossiyskoho Universiteta Druzhby Narodov. Seria Ahronomia i Zhivotnovodstvo, 10(1), 18-24 (in Russian).

Pechenkin, E. V., Sahirov, A. A., \& Horelic, O. V. (2013). Rost i razvitie krolikov raznykh porod [Growth and development of rabbits of different breeds]. Izvestiia OHAU, 6(44), 88-90 (in Russian).

Prola, L., Cornale, P., Renna, M., Macchi, E., Perona, G., \& Mimosi, A. (2013) Effect of breed, cage type, and reproductive phase on fecal corticosterone levels in doe rabbits. Journal of Applied Animal Welfare Science, 16, 140-149.

Samoyliuk, V. V. (2011). Osoblyvosti anatomiyi i topohrafiyi limfoidnykh utvoren kyshechnika porosiat misiachnoho viku [Features of anatomy and topography of intestinal lymphoid formations of month old piglets]. Veterynarna Medycyna, 95, 405-407 (in Ukrainian).

Sicherer, S. H., \& Sampson, H. A. (2010). Food allergy. Allergy and Clinical Immunology, 125, 116-125.

Stoyanovskiy, V. G., Kolomiyets, I. A., \& Kamratska, O. I. (2014). Topografichni osoblyvosti imunnykh struktur kyshechnika kroliv [Topographical features of immune structures of rabbits intestine]. Naukovyi visnyk Lvivskiy Natsionalniy Universitet Veterynarnoyi Medytsyny ta Biotekhnologiyi imeni S. Z. Gzhytskoho, 60, 308-313 (in Ukrainian).

Shubina, T. P., \& Choporova, N.V. (2015). Sravnitelnaya kharakteristica orhaniv pishchevareniya pushnykh zverei [Comparative characteristics of the digestive organs of fur-bearing animals]. Kontsept, 13, 4076-4080 (in Russian).
Tazzoli, M., Trocino, A., Birolo, M., Radaelli, G., \& Xiccato, G. (2015). Optimizing feed efficiency and nitrogen excretion in growing rabbits by increasing dietary energy with high-starch, high-soluble fibre, low-insoluble fibre supply at low protein levels. Livestock Science, 172, 59-68.

Trocino, A., Filiou, E., Tazzoli, M., Bertotto, D., Negrato, E., \& Xiccato, G. (2014). Behaviour and welfare of growing rabbits housed in cages and pens. Livestock Science, 167, 305-314.

Trocino, A., Fragkiadakis, M., Majolini, D., Carabaño, R., \& Xiccato, G. (2011). Effect of the increase of dietary starch and soluble fibre on digestive efficiency and growth performance of meat rabbits. Animal Feed Science and Technology, 165(3), 265-277.

Tumova, E., Bizkova, Z., Skrivanova, V., Chodova, D., Martinec, M., \& Volek, Z. (2014). Comparisons of carcass and meat quality among rabbit breeds of different sizes, and hybrid rabbits. Livestock Science, 165, 8-14.

Vakulenko, I. S., Danets, L. M., \& Aksonov, E. O. (2016a). Biologichni osnovy formuvannia myasnoyi productyvnosti kroliv [Biological bases of formation of rabbit meat productivity]. Efectyvne Krolivnytstvo i Zvimytstvo, 2, 13-21 (in Ukrainian).

Vakulenko, I. S., \& Petrash, V. (2016b). Formuvannia myasnoyi produktyvnosti kroliv u vikoviy dynamitsi [Rabbits meat productivity formation in the age dynamics]. Naukovo-Tekhnichnyi Biuleten Natsionalna Akademiya Ahrarnykh Nauk Ukrainy, 116, 21-29.

Vighi, G., Marcucci, F., Sensi, L., Di Cara, G., \& Frati, F. (2008). Allergy and the gastrointestinal system. Clinical and Experimental Immunology, 153, 3-6. 